\title{
Handbook of Psychiatry
}

\section{General Editor: MICHAEL SHEPHERD}

The Handbook of Psychiatry is a comprehensive, multi-author account of modern clinical psychiatry and its scientific foundations in five volumes. Many of the authors represent the so-called 'Maudsley' tradition, but the series is broadly-based and international in its psychobiological approach and will be of value to all practising psychiatrists and to graduate students of psychiatry and medicine.

\section{Volume 1: General Psychopathology}

\section{Edited by M. SHEPHERD and O. L. ZANGWILL}

Contributors: W. F. Bynum; R. H. Cawley; J. E. Cooper; E. Fischer-Homburger; T. C. N. Gibbens;

J. Hoenig; R. E. Kendell; F. Kraupl-Taylor; E. Miller; H. B. M. Murphy; F. Post; W. Robbins;

C. Scharfetter; M. Shepherd; J. Starobinski; O. Temkin; M. A. Wyke; O. L. Zangwill.

Hard covers £27.50 net

Paperback 89.95 net

\section{Volume 2: Mental Disorders and Somatic Illness}

\section{Edited by M. H. LADER}

Contributors: D. P. Birkett; M. R. Bond; J. L. Crammer; J. Cutting; G. W. Fenton; M. F. Folstein; A. H. Ghodse; J. L. K. Granville-Grossman; B. J. Gurland; A. D. Isaacs; R. Kumar; M. H. Lader; P. R. McHugh; C. D. Marsden; H. G. Morgan; I. Oswald; D. Ricks; M. Victor. Hard covers $£ 30.00$ net Forthcoming (September)

Paperback \&12.95 net

\section{Volume 3: Psychoses of Uncertain Aetiology}

\section{Edited by J. K. WING and LORNA WING}

Contributors: G. Ashcroft; P. Bebbington; D. H. Bennett; A. Clare; C. R. Cloninger; D. J. Cohen; J. Corbett; U. Frith; J. L. Gibbons; I. I. Gottesman; J. Gould; P. Graham; D. R. Hanson; E. H. Hare; S. R. Hirsch; P. Howlin; I. Kolvin; J. Leff; J. M. Neale; T. F. Oltmanns; E. S. Paykel; F. Post; J. D. Rainer; K. Rawnsley; Th. Reich; J. Rice; D. M. Ricks; R. Rodnight; P. Sainsbury; B. A. Shaywitz; E. Stromgren; B. Suarez; J. K. Wing; L. Wing; J. G. Young.

Hard covers $£ 25.00$ net Paperback E9.95 net

\section{The Origins of Psychotherapy}

Problems in Research and Public Policy

\section{Edited by DAVIDF. RICKS and BARBARA S. DOHRENWEND}

Research into the origins of psychotherapy raises important legal and ethical issues, as well as substantive and methodological ones. This volume offers an overview of current thinking about the etiology and prevention of mental illness in an era of computerised medical and psychiatric records and increased public concern about privacy. E22.50 net

\section{CAMBRIDGE UNIVERSITY PRESS}




\section{NOTES FOR CONTRIBUTORS}

PAPERS Papers for publication should be addressed to the Editor, Professor Michael Shepherd, Institute of Psychiatry, De Crespigny Park, Denmark Hill, London SE5 8AF. Contributors should send at least three copies of the text, tables, and figures. Copies other than the first may be xeroxed. The S.I. system should be adopted for text and figures. A short synopsis of about 50 words should be provided at the beginning of each article. Foreign quotations and phrases should be followed by a translation. Submission of a paper will be held to imply that it contains original work that has not been previously published and that it is not being submitted for publication elsewhere.

In addition to longer articles, the Editor is prepared to accept preliminary and brief communications of between 1500 and 2500 words.

Manuscripts must be typewritten on one side of the paper in double-spacing with wide margins. The following information must be given on a single separate sheet: (1) title and short title for running head (not more than 100 characters); (2) authors' names, and (3) department in which work was done. Footnotes on the same sheet should list: (i) the authors' present addresses if different from departments in which work was done; (ii) name and address of the author to whom correspondence should be addressed; (iii) receipt of grants. Authors who would like a reprint address to be printed should include this on their manuscript.

REFERENCES (1) In the text these should follow the Harvard system - that is, name followed by date: Brown (1970). If there are more than two authors the first author's name followed by et al. should be used, even the first time that the reference appears. (2) The list of references should be typed in alphabetical order on a separate sheet and should appear as follows: Brown, J., Williams, E. \& Wright, H. (1970). Treatment of heroin addiction. Psychological Medicine 1, 134-136. Journal titles should be given in full.

Books should be cited as follows: Brown, J. (1970). Psychiatric Research. Smith: Glasgow.

ILLUSTRATIONS Only essential figures and tables should be included. Photographs Unmounted photographs on glossy paper should be provided. Magnification scales, if necessary, should be lettered on these. Where possible, prints should be trimmed to column width (i.e. $70 \mathrm{~mm}$ ). Diagrams These will usually be reduced to $70 \mathrm{~mm}$ wide. Lettering should be in either Letraset or stencil, and care should be taken that lettering and symbols are of comparable size. Illustrations should not be inserted in the text, they should be marked on the back with figure numbers, title of paper, and name of author. All photographs, graphs, and diagrams should be referred to as figures and should be numbered consecutively in the text in Arabic numerals. The legends for illustrations should be typed on a separate sheet. Tables Tables should be numbered consecutively in the text in Arabic numerals and each typed on a separate sheet.

PROOFS AND OFFPRINTS Page proofs will be sent to the senior author. Corrections other than printer's errors may be charged to the author. Fifty offprints of each paper are supplied free; additional offprints are available according to a scale of charges if they are ordered when the proof is returned.

(C) Cambridge University Press 1983

CAMBRIDGE UNIVERSITY PRESS

The Pitt Building, Trumpington Street, Cambridge CB2 1RP

32 East 57th Street, New York, N.Y. 10022

Printed in Great Britain at the University Press, Cambridge 


\title{
Psychological Medicine
}

\author{
Volume 13 Number 3 August 1983
}

\section{CONTENTS}

EDITORIALS

Models of depression in primates

S. J. SUOM I

Relapse in schizophrenia: a review of

page 465

the concept and its definitions

I. R. H. FALLOON, G. N. MARSHALL,

J. L. BOYD, J. RAZANI AND

C. WOOD-SIVERIO

The idiot savant: flawed genius or clever Hans? B. HERMELIN AND N. O' CONNOR

Life events and psychological morbidity: the evidence from prospective studies C. TENNANT

CLARK, M. J.

A plastic power ministering to organisation': interpretations of the mind-body relation in late nineteenth-century British psychiatry

BAKER, H. F., RIDLEY, R. M., CROW,

T. J., BLOXHAM, C. A., PARRY, R. P.

AND TYRRELL, D. A. J.

An investigation of the effects of intracerebral injection in the marmoset of cytopathic cerebrospinal fluid from patients with schizophrenia or neurological disease

JOHNSTONE, E. C., CROW, T. J.,

FERRIER, I. N., FRITH, C. D., OWENS,

D. G. C., BOURNE, R. C. AND GAMBLE, S. J.

Adverse effects of anticholinergic medication on positive schizophrenic symptoms

SMIGAN, L. AND PERRIS, C. Memory functions and prophylactic treatment with lithium

FOLSTEIN, S. E., ABBOTT, M. H., CHASE,

G. A., JENSEN, B. A. AND FOLSTEIN, M. F. The association of affective disorder with Huntington's Disease in a case series and in families

VANDEREYCKEN, W. AND PIERLOOT, R. The significance of subclassification in anorexia nervosa: a comparative study of clinical features in 141 patients

ZUBIN, J., MAGAZINER, J. AND

STEINHAUER, S. R.

The metamorphosis of schizophrenia: from chronicity to vulnerability

MANN, A. H., WAKELING, A., WOOD, K., MONCK, E., DOBBS, R. AND

SZMUKLER, G.

Screening for abnormal eating attitudes and psychiatric morbidity in an unselected population of 15-year-old schoolgirls

ERRMAN, H. E., BALDWIN, J. A. AND CHRISTIE, D.

A record-linkage study of mortality and general hospital discharge in patients diagnosed as schizophrenic
DEROGATIS, L. R. AND MELISARATOS, N. The Brief Symptom Inventory: an introductory report

MELLINGER, G. D., BALTER, M. B.,

UHLENHUTH, E. H., CISIN, I. H.,

MANHEIMER, D. I. AND RICKELS, K. Evaluating a household survey measure of psychic distress

WILLIAMS, P. Factors influencing the duration of treatment with psychotropic drugs in general practice: a survival analysis approach

BUR VILL, P. W. AND KNUIMAN, M. W. The influence of minor psychiatric morbidity on consulting rates to general practitioners

TAYLOR, P., MAHENDRA, B. AND

GUNN, J. Erotomania in males

MAACK, L. H. AND MULLEN, P. E. The Doppelgänger, disintegration and death: a case report

WILKINSON, D. G., TOONE, B. K. AND

GREER, $S$.

Medical students' attitudes to psychiatry at the end of the clinical curriculum

BRIEF COMMUNICATION

A follow-up of 'new' long-stay patients in Camberwell, 1977-82 T. WYKES

PRELIMINARY COMMUNICATIONS The natural history of schizophrenia: a 5-year prospective follow-up of a representative sample of schizophrenics by means of a standardized clinical and social assessment

D. C. WATT, K. KATZ AND M. SHEPHER D

Cognitive functions in tardive dyskinesia M. E. WOLF, J. J. RYAN AND A. D. MOSNAIM

RESEARCH REPORT

Psychiatric Clinic of the Free

University of Berlin; Department of Clinical Psychiatry and Polyclinic

(Psychiatrische Klinik der Freien Universität Berlin; Abteilung für

Klinische Psychiatrie und Poliklinik)

H. HELMCHEN

BOOK REVIEWS

Principles of Neural Science J. R. SMYTHIES

Schizophrenia: The Epigenetic Puzzle D. F. ROBERTS

Temperamental Differences in Infants and Young Children C. E. STROUD

Social Work and Primary Health Care M. JEFFER Y S

What is Psychotherapy? 